A. Klimczuk, M. Klimczuk-Kochańska, Dual Labor Market, [in:] N. Naples, A. Wong, M.

Wickramasinghe, R.C. Hoogland (eds.), The Wiley-Blackwell Encyclopedia of Gender and Sexuality

Studies, Wiley-Blackwell, Hoboken, New Jersey 2016, pp. 1-3

http://dx.doi.org/10.1002/9781118663219.wbegss529.

\title{
Dual Labor Market
}

ANDRZEJ KLIMCZUK

Warsaw School of Economics, Poland

MAGDALENA KLIMCZUK-KOCHANSKA

University of Warsaw, Poland

The dual labor market theory is one of the primary explanations for the gender differences in earnings. It shows that gender inequality and stereotypes lead to employment of men and women in different segments of the labor market and occupational gender segregation. These differences result in the overrepresentation of women in low-paying, low-status occupations compared with men. This theory is based on the hypothesis that such markets are divided into segments, which are divided by a separate system of rules, job behavior requirements, and different skills.

The dual labor market theory was introduced by American institutional economists, especially by Peter B. Doeringer and Michael J. Piore (1971), in their research on programs for combating poverty, unemployment, and discrimination. Programs were aimed to increase the education and mobility of employees. Analysis of the results showed their low efficiency and the presence of rather isolated areas of the labor market. The employees had a particularly unfavorable situation (unstable jobs, low wages, lack of promotion opportunities, lack of links between a chance to work, and efficiency and education). Explaining such labor division is the assumption that it is the result of employee characteristics that define their work environment and lifestyle (such as gender, age, and race). For example, human resources policies include the preferences for recruiting of white male workers to managerial positions by offering training, financial bonuses, promotion, and job security.

The dual labor market theory allows the analysis of various issues. For example, barriers to satisfying the structural labor demand by women and teenagers, availability of unstable and low productivity jobs in advanced economies, employment of immigrants in jobs not attractive to local workers, barriers to promote the unattractive jobs by market mechanisms such as raising wages, and acceptance of unattractive jobs by vulnerable social groups (Kogan 2007).

Differences between the labor markets include the availability of jobs for job seekers, the received and proposed remuneration, the level of employment stability, and the opportunity for professional development. The dual labor market theory divides the economy into primary 
A. Klimczuk, M. Klimczuk-Kochańska, Dual Labor Market, [in:] N. Naples, A. Wong, M.

Wickramasinghe, R.C. Hoogland (eds.), The Wiley-Blackwell Encyclopedia of Gender and Sexuality

Studies, Wiley-Blackwell, Hoboken, New Jersey 2016, pp. 1-3

http://dx.doi.org/10.1002/9781118663219.wbegss529.

(internal) and secondary (external) segments (Loveridge and Mok 1979; Garz 2013).

Internal labor markets traditionally dominated by white males ensure institutions and rules that provide promotion systems for employees and extensive career ladders (the distinction between the upper-tier, white collar, and lower-tier blue-collar ladders). Wages are based here on job evaluations and firm-specific skills that support long-term relationships between employers and employees with stable and permanent employment. The primary segment is, therefore, characterized by high wages, attractive working conditions, employees who actively identify with the companies, jobs in large companies with a strong market position and importance for the economy, voluntary payments, employment stability, opportunities for advancement, and the strong position of mainly male trade unions in their efforts to respect the rights and privileges of employees. The unemployment of workers from the primary segment is characterized as an involuntary condition. Such workers do not focus on job seeking but tend to wait or accept less attractive work temporarily. They trust that changes in the economy or the industry will lead to regaining the clearly identified positions from which they have been laid off.

External labor markets are closer to the assumptions of the neoclassical theory, dominated by women and minorities, and contain low-paying and low-status jobs. Such markets are in some respect created by discrimination ("the glass ceiling"). Key features are less attractive jobs (care and domestic work, the helping professions), lower wages that are often poverty level or below (the gender gap in earnings), the filling of vacancies by the market rather than by internal promotions, a requirement of general skills that can be easily replaced by easy hiring and firing, poor working conditions, fewer opportunities to advance, and high absenteeism. Workers may quit because of a dislike of a particular supervisor and may show little respect for the company goals and values. Such markets exist mainly in general industries and serve as buffer stocks in concentrated industries during expansionary periods of business cycles.

There are several reasons for the labor market duality and barriers that prevent mobility between segments (Doeringer and Piore 1971; Luck 1991; Martin 1992). First, it is supported by the strategies of firms to maximize profits with little opportunity for mobility between the segments. Second, jobs in a particular sector provide individuals' histories, attitudes, levels of aspirations, expectations, and orientations to work that distinguish them from the workers in other markets. Third, the disadvantaged start in the labor market begins with socialization by family and school and different social expectations, for example, to pursue traditional women's 
A. Klimczuk, M. Klimczuk-Kochańska, Dual Labor Market, [in:] N. Naples, A. Wong, M.

Wickramasinghe, R.C. Hoogland (eds.), The Wiley-Blackwell Encyclopedia of Gender and Sexuality

Studies, Wiley-Blackwell, Hoboken, New Jersey 2016, pp. 1-3

http://dx.doi.org/10.1002/9781118663219.wbegss529.

domains such as motherhood and to avoid science and authority. Fourth, there are various forms

of labor supply such as flexible work arrangements and part-time work that may maintain employment in the external labor markets by prioritizing childcare, education, or other nonoccupational activities.

SEE ALSO: Division of Labor, Gender; Employment Discrimination; Gender Wage Gap; Glass Ceiling and Glass Elevator; Occupational Segregation; Work-Family Balance

\section{REFERENCES}

Doeringer, Peter B., and Michael J. Piore. 1971. Internal Labor Markets and Manpower Analysis. Lexington, MA: Heath.

Garz, Marcel. 2013. "Labour Market Segmentation: Standard and Non-Standard Employment in Germany." German Economic Review, 14(3): 349-371.

Kogan, Irena. 2007. Working Through Barriers: Host Country Institutions and Immigrant Labour Market Performance in Europe. London: Springer.

Loveridge, Ray, and Albert L. Mok. 1979. Theories of Labour Market Segmentation: A Critique. The Hague: Martinus Nijhoff Social Sciences Division.

Luck, Maura. 1991. "Gender and Library Work: The Limitations of Dual Labour Market Theory." In Working Women: International Perspectives on Labour and Gender Ideology, edited by Nanneke Redclift and M. Thea Sinclair, 25-40. London: Routledge.

Martin, Patricia Y. 1992. “Gender, Interaction, and Inequality in Organizations.” In Gender, Interaction, and Inequality, edited by Cecilia L. Ridgeway, 208-231. New York: Springer.

\section{FURTHER READING}

Ghilarducci, Teresa, and Mary Lee. 2005. "Female Dual Labour Markets and Employee Benefits.” Scottish Journal of Political Economy, 52(1): 18-37.

Hirsch, Eric. 1980. “Dual Labor Market Theory: A Sociological Critique.” Sociological Inquiry, 50(2): 133 - 145.

Meyer, Christine S., and Swati Mukerjee. 2007. "Investigating Dual Labor Market Theory for Women.” Eastern Economic Journal, 33(3): 301-316. 